\begin{tabular}{ll|l} 
Case Reports in & \begin{tabular}{l} 
Case Rep Gastroenterol 2017;11:500-503 \\
\cline { 2 - 3 } Gastroenterology
\end{tabular} & $\begin{array}{l}\text { DOI: } 10.1159 / 000479550 \\
\text { Published onlIne: August 23, 2017 The Author(s) } \\
\text { Published by S. Karger AG, Basel } \\
\text { www.karger.com/crg }\end{array}$ \\
\cline { 2 - 3 } & $\begin{array}{l}\text { This article is licensed under the Creative Commons Attribution-NonCommercial } 4.0 \\
\text { International License (CC BY-NC) (http://www.karger.com/Services/OpenAccessLicense). } \\
\text { Usage and distribution for commercial purposes requires written permission. }\end{array}$
\end{tabular}

Single Case

\title{
Ascending Cholangitis due to Heavy Lifting
}

\author{
M.J. Bakkum R.J.L.F. Loffeld \\ Department of Internal Medicine, Zaans Medisch Centrum, Zaandam, The Netherlands
}

\section{Keywords}

Cholangitis · Heavy lifting · Gallstones · Complicated gallstone disease

\begin{abstract}
Gallstone disease is the most common risk factor for cholangitis. In an anatomically normal bile duct system, cholangitis does not occur without the presence of stones. Endoscopic retrograde cholangiography with papillotomy and stone extraction is a well-established curative therapy for gallstones in the common bile duct. More important, papillotomy prevents recurrent episodes. The present case report describes a 73-year-old male with recurring cholangitis in a clear bile duct system after previous papillotomy. An etiology of duodenal reflux into the common bile duct due to heavy lifting is proposed.

(C) 2017 The Author(s)

Published by S. Karger AG, Basel
\end{abstract}

\section{Introduction}

Cholangitis is a well-known complication of gallstone disease, especially in case of stones in the common bile duct. The primary therapy is endoscopic retrograde cholangiography (ERC) with or without papillotomy and stone extraction. While cholecystectomy is

Zaans Medisch Centrum

PO Box 201, NL-1500 EE Zaandam (The Netherlands)

E-Mail loffeld.r@zaansmc.nl 
curative with respect to stones in the gallbladder, the procedure does not change the quality of the bile. In 7-20\% of patients undergoing cholecystectomy, stones are found in the common bile duct. Moreover, new stones may develop over time in the common bile duct. These stones are a frequent cause of cholangitis [1].

We describe the case of a patient with recurring episodes of cholangitis in a short period even after clearing the common bile duct of stones.

\section{Case Presentation}

A 73-year-old male patient was sent to the emergency department because of high fever $\left(40^{\circ} \mathrm{C}\right)$ with chills and right upper abdominal colicky pain. He complained of nausea and had dark urine as well as jaundice. His medical history revealed a cholecystectomy 33 years earlier. Fifteen year before the current presentation he was diagnosed with stones in the common bile duct for which he underwent ERC, papillotomy, and stone extraction. He was without complaints until the current presentation. Laboratory results were consistent with cholestasis (Table 1). Ultrasound imaging showed dilated intra- and extrahepatic ducts with the suggestion of stones in the common bile duct. Aerobilia was present, and sludge was seen in the hilar region. The patient was treated for ascending cholangitis with fluid resuscitation and intravenous antibiotics. An ERC was performed. The previous papillotomy was not visible anymore, hence a new one was done. Many stones were extracted from the common bile duct.

The patient recovered well. However, 3 months later he experienced recurrent complaints. Ultrasound showed retained stones in the common bile duct. In two ERC sessions all these stones were removed. Contrast cholangiography showed complete clearance of the bile ducts.

Over the next 4 months the patient experienced four episodes of chills with a temperature of $38-39^{\circ} \mathrm{C}$ and right upper abdominal complaints without colics. The laboratory findings during these episodes are shown Table 1. Repeated ultrasound investigations showed no abnormalities. The bile ducts were normal. On each occasion the patient received antibiotics, with excellent clinical response. Blood cultures remained negative.

Renewed medical history revealed that the patients had done heavy lifting work, such as moving furniture, the day before each of the four episodes. It was concluded that the repeated episodes of cholangitis resulted from influx of duodenal contents into the common bile duct due to heavy lifting in the presence of a papillotomy. The patient was advised to refrain from further lifting. He has been doing well ever since. The cholangitis has not recurred for over 8 months.

\section{Discussion}

The present patient developed stones in the common bile duct for the second time since a previous cholecystectomy and a previous papillotomy. This is not unique. Around $10 \%$ of patients will develop micro- or macrolithiasis in the common bile duct after cholecystectomy. In a study from Korea, the stones occurred in 15 of 144 patients $(10.4 \%)$ during a longer 
follow-up period [2]. This was confirmed in several other studies [3-5]. Stones in the common bile duct usually originate in the gallbladder [6]. Risk factors for stone formation are bile duct dilatation, biliary stricture, and angulation of the common bile duct due to anatomical abnormalities [7, 8]. Already more than 20 years ago, papillotomy with stone extraction and biliary drainage was recommended in patient with ongoing cholangitis [9]. Whether cholecystectomy prevents recurrent cholangitis is a matter of debate. Hui et al. [10] studied in a prospective study recurrence of cholangitis in patients undergoing cholecystectomy or not and concluded that the surgical procedure did not prevent recurrence. However, papillotomy was found to be protective.

This case demonstrates once again that recurrent cholangitis can develop after incomplete drainage or retained stones [11]. Extraction is not always successful in one procedure. In a large study, $77 \%$ of cases underwent successful extraction in one session [12]. More importantly, this case describes recurrent cholangitis in a bile duct system without stones with previous papillotomy. To the best of our knowledge, this is highly extraordinary. The events are suggestive of a causal relationship between heavy lifting and cholangitis. Exercise of any kind will elevate intraabdominal pressure. Hence, it is plausible to assume that duodenal contents may reflux into the common bile duct in the presence of a papillotomy. This may cause bacterial cholangitis. A similar etiology of recurrent cholangitis was described in patients who had undergone biliary bypass or pancreatoduodenectomy [13]. The simple advice to abstain from heavy lifting has effectively helped our patient.

\section{Statement of Ethics}

The patient gave permission to publish his case.

\section{Disclosure Statement}

There are no conflicts of interest.

\section{References}

1 Raraty MG, Finch M, Neoptolemos JP: Acute cholangitis and pancreatitis secondary to common duct stones: management update. World J Surg 1998;22:1155-1161.

-2 Oak JH, Paik CN, Chung WC, Lee KM, Yang JM: Risk factors for recurrence of symptomatic common bile duct stones after cholecystectomy. Gastroenterol Res Pract 2012;2012:417821.

-3 Tanaka M, Ikeda S, Yoshimoto H, Matsumoto S: The long-term fate of the gallbladder after endoscopic sphincterotomy. Complete follow-up study of 122 patients. Am J Surg 1987;154:505-509.

-4 Bergman JJ, van der Mey S, Rauws EA, Tijssen JG, Gouma DJ, Tytgat GN, Huibregtse K: Long-term followup after endoscopic sphincterotomy for bile duct stones in patients younger than 60 years of age. Gastrointest Endosc 1996;44:643-649.

5 Ueno N, Ozawa Y, Aizawa T: Prognostic factors for recurrence of bile duct stones after endoscopic treatment by sphincter dilation. Gastrointest Endosc 2003;58:336-340.

6 Williams EJ, Green J, Beckingham I, Parks R, Martin D, Lombard M; British Society of Gastroenterology: Guidelines on the management of common bile duct stones (CBDS). Gut 2008;57:1004-1021. 


\section{Case Reports in Gastroenterology}

Cheon YK, Lehman GA: Identification of risk factors for stone recurrence after endoscopic treatment of bile duct stones. Eur J Gastroenterol Hepatol 2006;18:461-464.

-8 Keizman D, Shalom MI, Konikoff FM: Recurrent symptomatic common bile duct stones after endoscopic stone extraction in elderly patients. Gastrointest Endosc 2006;64:60-65.

Boender J, Nix GA, de Ridder MA, Dees J, Schütte HE, van Buuren HR, van Blankenstein M: Endoscopic sphincterotomy and biliary drainage in patients with cholangitis due to common bile duct stones. Am J Gastroenterol 1995;90:233-238.

10 Hui CK, Lai KC, Yuen MF, Ng MM, Lam SK, Lai CL: Role of cholecystectomy in preventing recurrent cholangitis. Gastrointest Endosc 2002;56:55-60.

11 Vandervoort J, Soetikno RM, Tham TC, Wong RC, Ferrari AP Jr, Montes H, Roston AD, Slivka A, Lichtenstein DR, Ruymann FW, Van Dam J, Hughes M, Carr-Locke DL: Risk factors for complications after performance of ERCP. Gastrointest Endosc 2002;56:652-656.

12 Zinsser E, Hoffmann A, Will U, Koppe P, Bosseckert H: Success and complication rates of diagnostic and therapeutic endoscopic retrograde cholangiopancreatography - a prospective study. Z Gastroenterol 1999;37:707-713.

13 Touzios JG, Krzywda B, Nakeeb A, Pitt HA: Exercise-induced cholangitis and pancreatitis. HPB (Oxford) 2005;7:124-128.

Table 1. Laboratory results on the several occasions of presentation

\begin{tabular}{lrrrrrrr}
\hline & January & April & May & June & June & July & September \\
\hline AST, U/L & 94 & 357 & 350 & - & 116 & 40 & 83 \\
ALT, U/L & 163 & 346 & 32 & 33 & 111 & 39 & 70 \\
GGT, U/L & 1,486 & 816 & 161 & 193 & 495 & 204 & 249 \\
ALP, U/L & 420 & 143 & 100 & 137 & 176 & 173 & 159 \\
CRP, mg/L & 80 & 45 & 58 & 15 & 55 & 12 & 58 \\
Bilirubin, $\mu$ mol/L & 40 & 75 & 23 & 13 & 45 & 15 & 23 \\
Ultrasound & stones & stones & stones & na & na & na & na
\end{tabular}

Normal values: AST <35 U/L, ALT <45 U/L, GGT < 55 U/L, ALP <120 U/L, bilirubin <21 $\mu$ mol/L. ALP, alkaline phosphatase; ALT, alanine transaminase; AST, aspartate transaminase; CRP, C-reactive protein; GGT, gamma-glutamyl transpeptidase; na, no abnormalities. 